\title{
AUSTRALIAN AND SOUTH AFRICAN PERSPECTIVES ON THE IMPLEMENTATION OF FLEXIBLE WORK PRACTICES (FWP): AN EXPLORATORY STUDY
}

\author{
ALETTA ODENDAAL \\ Programme Group Human Resource Management \\ Technikon SA \\ GERT ROODT \\ Department of Human Resource Management \\ Rand Afrikaans University
}

\begin{abstract}
The purpose of this study was to identify examples of good and innovative practices of Flexible Work Practices to benchmark against and then to use the information to develop strategies of implementation that will assist South African organisations to emulate their success. One hundred-and-twenty (120) individuals, representing different stakeholder groups were requested to complete a questionnaire, based on an Australian study. Comparative findings of both countries strongly confirmed variables that are positively associated with the adoption and successful implementation of Flexible Work Practices (FWP).
\end{abstract}

\section{OPSOMMING}

Die doel van hierdie studie was om voorbeelde van goeie en innoverende gebruike van Buigsame Werkspraktyke te identifiseer ten einde daarteen te kan vergelyk, en dan om hierdie inligting te gebruik ten einde implementeringstrategieë te ontwikkel wat Suid Afrikaanse maatskappye kan gebruik om sukses na te volg. Honderd en twintig (120) individue, wat verskillende belangegroepe verteenwoordig, is genader om ' $n$ vraelys, gebaseer op ' $n$ Australiese studie, te voltooi. Vergelykende bevindinge van beide lande bevestig veranderlikes wat positief geassosieer word met die aanvaarding en suksesvolle implementering van Buigsame Werkspraktyke (BWP).

Over recent years, the environment in which companies operate has changed considerably. The global economy can be seen as a driving force behind this change and has led to extensive restructuring in most organisations. Companies are faced with a need to achieve greater economic efficiency, and to adapt more quickly to changing market conditions. Seeking to become more competitive on a global scale, organisations have looked for ways to become more flexible in order to respond better to fluctuations in demand for products and services. There is agreement in the literature that one form of change has been a move away from mass-production in manufacturing, and bureaucratic control in all sectors, towards flexible forms of work organisation. In this regard Axel (1996) states that flexibility will be a defining attribute for organisations hoping to survive in the $1990 \mathrm{~s}$ and beyond. Familiar but rigid organisational structures and operating procedures that worked well in more predictable times are, according to Olmsted and Smith (1997), no longer appropriate in today's ever-changing business environment.

Changing demographics of work forces around the world, and particularly in South Africa, highlight the growing importance of workplace flexibility. Even at a macro-economic level the increased use of flexibility in the workforce has been mentioned in the Growth, Employment and Reconstruction (GEAR) policy as one of the factors that can help to alleviate the current labour-market crisis in South Africa (Appia-Mfodwo, 1998). Flexibility can, according to Olmsted and Smith (1997), be interpreted from two perspectives that of the organization and that of the employees:

1. For the organization, flexibility means being able to adjust quickly to changing economic conditions: expanding, contracting or reallocating labour supply as needed, and improving service in order to become more competitive by increasing productivity and decreasing costs.

Requests for copies should be addressed to: A Odendaal, Programme in Group Human Resource Management, Technikon SA, Private Bag X6, Florida, 1710
2. To employees, flexibility means being able to adjust work time or change workplace when their personal needs are in conflict with their work schedule.

Both perceptions reflect a working world where people and organisations are under increasing pressure to do more with less and need to be able to react quickly to external demands and ongoing change. In the process, new concepts have emerged. Among them are: employee empowerment, participative management and self-managed work teams. New technologies have further facilitated global communication and, at the same time, have blurred boundaries about where and when work is done (McLagan \& Nel, 1995; Odendaal \& Roodt, 1998). In this regard the emergence of examples of FWP such as flexitime, job sharing, compressed workweeks, telecommuting/telework, and work sharing is the result of efforts to make organisations less rigid and to initiate policies that allow the employer and employee to function better.

Background to the research project

Recent reviews from Becker and Huselid (1998); Gittleman, Horrigan and Joyce (1998); Ichniowski, Kochan, Levine, Olson and Strauss (1996); Kling (1995) provided substantial evidence that companies that report the use of FWP tend to enjoy better financial performance and higher levels of productivity, than those do not.

In addition to the above, a review by the Organisation for Economic Co-operation and Development (OECD, 1999) found that the beneficial effect is stronger when flexible practices are used in combination both with each other and with support from other human resource practices, such as training and appropriate compensation policies.

Owing to the association of FWP with better economic performance, many organisations are showing an increasing interest in FWP. An assessment of the current state of evidence 
on the implementation of FWP across ten European countries, USA, Australia and Japan indicates a substantial increase between 1990 and 1995 of the implementation of FWP (OECD, 1999, p.181). An examination of the incidence of practices across countries suggests that comparisons can be drawn between countries with similarities between national and workplace industrial relations systems. In this regard, reference can be made to the study of Horwitz, Cameron and Brosnan (2000, p. 82 ) on the use of numerical and temporal types of flexibility in South Africa, Australia and New Zealand. The three-country survey indicated that a moderate proportion of employees are engaged in various types of non-standard employment. Significantly, workplaces in all three countries reported that they had increased their use of FWP in the recent past and intended to increase it in the future.

South Africa, however, is a country in the process of transition, and the changes in the workplace and workforce initiated by Labour Legislation as well as the implementation of the National Qualification Framework (NQF) emphasised the need to move from a time-control approach to an outcomes-control approach. Major factors driving the outcomes-control approach are, firstly, the changing nature of work. In this regard Skyrme (1994, p. 98) identified that more work is information based, with estimates suggesting that more than 60 percent of work activity in developing countries is information or knowledge based. The lifetime of business processes is diminishing and work is becoming less structured with tasks no longer compartmentalised into specialised units of activity or job descriptions. Secondly, the number of women in the workforce is increasing and with them they carry the primary responsibility for the care of their dependants. Companies need to address women's needs if they want to tap into their productive potential. The traditional family with a full-time homemaker and a fulltime breadwinner without domestic responsibilities is no longer the norm. The majority of employees have family responsibilities.

It is, however, not just the diversification of the workforce that necessitated change. Other factors include the transition from a manufacturing to a service-oriented job market, advances in technology, problems with commuter peak hours, and the emergence of a global economy. In addition to the above, Horwitz et al. (2000) indicated that the law governing employment, industrial relations and bargaining systems, and social security provisions tend still to be predicated upon standard employment, i.e. hours worked. However, if a significant proportion of the workforce is employed under nonstandard employment conditions the regulatory requirements need to be revisited.

Closely related changes in South Africa and Australia concerning the increase in the number of women in the workforce, as well as the introduction of affirmative action (Australia) and employment equity (South Africa), have long been acknowledged. Various acts and laws have appeared in both countries to end discrimination in employment practices on the basis of gender, race, colour, age, religion and ethnicity (Robbins, Millett, \& Cacioppe, 1998, p. 58). Alongside these changes are changing perceptions and views about employment practices. These new perceptions have led to the acknowledgement that different values and customs make flexibility essential.

Against this background it could be postulated that some similarities exist in terms of the management of flexibility in Australia and South Africa. It has been hypothesised that organisations in South Africa can benefit from the experience of organisations in Australia. An Internet search into the application of FWP in the public sector in Australia has revealed that the Attorney Generals Department is increasingly regarded as a leader in the implementation of different options of flexibility. In recognition of their achievement in this area, researchers approached them to share information about strategies that have resulted in the effective and equitable implementation of alternative work arrangements.

\section{Aims and objectives of the research}

Limited empirical evidence is available in South Africa about the implementation of FWP. To assist South African companies to implement FWP, the major objectives of this study were to:

- firstly, determine by means of a literature review examples of good innovative practices and then to develop a strategy for implementation;

- secondly examine by means of a questionnaire the perception of stakeholders in South Africa, on the basis of a study in Australia; and

- thirdly, compare the results obtained, where available, with the Australian data.

It was hypothesised that the outcomes of the research project will provide a model of effective intervention that will assist other organisations in South Africa to implement FWP effectively. It was further hypothesised that the identification of barriers by all stakeholders will assist the institution to plan proactively the successful implementation of FWP.

\section{Defining flexible work options}

In order to research the implementation of FWP it is necessary to define and operationalise the concept of flexibility. The problem is that there is no accepted definition. Although it seems fair to say that different researchers have the same broad set of practices in mind, different authors place emphasis on somewhat different sets of dimensions. An example is a model of the flexible firm with emphasis on a "core" set of workers in a conventional employment arrangement with a "periphery" of workers in a non-conventional arrangement (Atkinson, 1984). In this regard FWP will fall in the latter category, whereas Blyton (1991) differentiates between functional, numerical, temporal and wage flexibility. Horwitz (2001, p. 257) summarises Blyton's typology of work flexibility as follows: Firstly, "task or functional flexibility" refers to the adaptability and mobility of employees to undertake a range of tasks, including multi-skilling and job rotation. "Numerical flexibility" relates to varying the size and structure of the work force in response to changes in demand. "Temporal flexibility" involves various patterns of work hours, shifts, part-time work, working from home and temporary work in response to changing economic, technological and demographic demands. Lastly "wage flexibility" includes a shift from uniform pay systems towards individualised pay, with variability based on performance. Reviewing FWP in South Africa and using Blyton's typology, Horwitz (2001, p. 264) concluded that there is no consistent and uniquely South African approach to flexibility. Whether it occurs or not, the form it takes and the level at which it is negotiated varies sectorally. Cohesiveness of bargaining structures, union approaches to flexibility, industry structure, labour and product market seem to be variables which shape FWP.

For the purpose of this study, the definition of FWP as operationalised by the Australian study will be used to enable a comparative analysis. FWP can thus be seen as employment arrangements that aim to achieve the best possible match between the business interest of employers and the personal/professional interests of individual employees in order to improve productivity. In this regard FWP is seen as a management tool and not as a benefit (Johnson, 1997; Olmsted \& Smith, 1997; Robbins et al., 1998). No attempt, however, will be made to outline the advantages 
and disadvantages of the different options of flexibility, nor to explore the different meanings that the options might have in the different countries. The different options will be listed using the classification of the Attorney General's Department (1999), purely to make the reader aware of the magnitude of dimensions that can be classified under FWP:

\section{Restructured Full-time Work Arrangements}

Working from home/telecommuting/telework/virtual office New technological opportunities such as electronic mail (e-mail) and GroupWare networking have created a new alternative in work scheduling called telework - it can be short term or permanent. Telework refers to remote working of some sort (working at an alternate work site that is away from the main or primary work site typically used by the organisation). In this regard it is important to carefully select employees with appropriate characteristics and job types that would succeed in a remote environment. Not all job types, skill sets or personality types are suitable for telework.

\section{Flexible working hours}

The standard business schedule is 8 a.m. to 5 p.m. These are conventional starting and quitting times for many workers. A variation of this schedule is flexitime, where an employee is allowed to start and end the workday at times other than the conventional eight to five. The number of work hours remains the same, but the employee decides when the workday starts and ends. The employer determines the core period in which all employees must be present - called flexible bands, e.g. with a core period of 9:30 a.m. to 3:00 p.m. - one band may extend from 6:30 to 9:30 a.m. and the other from 3:00 p.m. to 6:00 p.m. Employees then choose their arrival and departure times within these bands to schedule an eight-hour day.

\section{Compressed work-week}

The hours of work per day are increased so that the hours worked per week are still the same. An employee may, for instance, work a 40-hour week consisting of four ten-hour working days. Employers are advised to take note of the limitations on working hours per day as proposed by the Basic Conditions of Employment Act 75/1997.

\section{Reduced Work Time Options}

Part-time work

Working, on a continuing basis, for less than the full-time weekly hours of the job at mutually agreed times, for example:

- 3 full days per week,

- $5 \mathrm{X}^{1 / 2}$ days per week, or

- 8 days over 4 weeks.

\section{Job sharing}

Voluntarily sharing the duties and responsibilities of one job amongst part-time employees and/or full-time employees. This can be on a continuous basis or for a specific period.

Part-time leave

Leave taken by full-time employees to work part-time for a specific period, e.g. part-time leave without pay.

Variable year work

Unpaid leave taken for a year or more after a number of years of work, or leave taken by full-time employees on a one-to-one basis to work part-time for a specific period.

\section{Career break schemes}

Leave without pay for an extended specified period with the right to return to a position at the same level, for example:

- Full-time studies, or

- Overseas travel.
Leave for family and community care responsibilities Short-term leave for a number of hours or days to meet family or community needs. This can be available through paid family and community service leave, or leave without pay.

\section{METHOD}

The study is essentially exploratory and based on action research. It will, however, compare and contrast available data on the perceptions of employees in South Africa and Australia with regard to the implementation of flexibility. The method of research used in this study will subsequently be discussed.

\section{Sample}

Theoretical evidence implies that the successful introduction of FWP may depend upon the presence of the specific management expertise required, or upon the workforce already possessing a certain level of skills or having the ability to acquire them relatively easily (Betcherman, 1997). Employee attitudes and the industrial relations framework in which the organisation operates are according to Levine (1990) and Locke, Kochan and Piore (1995), also likely to be important. It is evident that the characteristics of the workplace, e.g. the size of the employer, the nature of the industry, the presence of a trade union all play a role in making a decision on whether or not FWP should be implemented.

Against this background the research design was based on action research involving all stakeholders in an academic institution with strong industry involvement that identified the need to implement flexibility. The project focused on possible implementation of FWP within a specific division of the institution and, therefore, the sample was one of convenience and not representative of the population. For the purpose of this study the stakeholder groups need to be defined to avoid misinterpretations.

- Students: The SRC was approached to represent the views of students.

- Employees: Refer to academic and administrative staff members excluding management and the Human Resources Department.

- Management: Refer to postgrade-level 1-3.

- Unions: The leadership of the unions was approached to represent the views of organised labour.

- HR Department: The assumption was made that HR would play a major role in implementing FWP and was identified, therefore as a separate stakeholder.

The sample of convenience included managers, employees, clients (students) and the trade union. The sample size included 120 questionnaires, which were distributed in the manner illustrated in Table 1.

TABLE 1

SAMPLE DISTRIBUTION

\begin{tabular}{lccc}
\hline Stakeholder group & $\begin{array}{c}\text { Questionnaires } \\
\text { distributed }\end{array}$ & $\begin{array}{c}\text { Questionnaires } \\
\text { received }\end{array}$ & $\begin{array}{c}\text { Response } \\
\text { rate }\end{array}$ \\
\hline Students & 20 & 12 & $60 \%$ \\
Human Resources & 15 & 2 & $13 \%$ \\
Management & 15 & 11 & $73 \%$ \\
Employees & 50 & 30 & $60 \%$ \\
Unions & 20 & 4 & $20 \%$ \\
\hline TOTAL & $\mathbf{1 2 0}$ & $\mathbf{5 9}$ & $49 \%$ \\
\hline
\end{tabular}

After the elimination of questionnaires with missing values, 55 questionnaires were used in the final analysis. 


\section{Measuring instrument}

The questionnaire that was used for this study was a duplication of an Australian survey conducted at the Attorney General's Department in 1999. The questionnaire consists of four open-ended questions, examining the perceptions of all stakeholders involved in the implementation of FWP. The stakeholders were invited to express their views on the advantages, disadvantages, barriers and possible solutions to effective implementation of FWP. Respondents were given two weeks to complete the questionnaire. During this time the institution in South Africa was exposed to industrial action that might have had an influence on the response rate of, especially, the unions and the Department of Human Resources.

\section{Procedure}

Individuals from the different stakeholder groups were requested to complete the questionnaire. The leadership of the unions and students were involved in the circulation of the questionnaires to union members and students respectively. A cover letter was attached to the questionnaire, supplying information about the definition of flexible work practices as well as the different options available. The statistical analysis of the data was descriptive and consisted of determining the frequencies of responses received. The first step was to identify themes under each question. Responses were then grouped under each theme. Thirdly, the frequency that a response under a theme occurred for each stakeholder group was determined. The perceptions of the different stakeholders in South Africa and Australia with regard to flexible work practices will subsequently be discussed.

\section{RESULTS}

Findings on stakeholders' perceptions with regard to the advantages, disadvantages, barriers and possible solutions are detailed in the different tables below:

Potential advantages of FWP as presented in Table 2 were identified as follows:

- $55 \%$ believed that the implementation of FWP would lead to the effective utilisation of time. In this regard reference was made to time for postgraduate studies and self-development, as well as time used up travelling to and from the workplace. Students were of the opinion that FWP will make lecturers available at hours that differ from the conventional office hours and that there might be more time available for contact sessions.
- $45 \%$ reported that FWP would improve productivity.

- $42 \%$ (compared to $45 \%$ of Australian respondents) reported on the personal benefit of being in a position to balance work and family life. There was a general perception that absenteeism and time off from work are linked to meeting family and personal needs.

- $36 \%$ reported the benefit of cost savings for the institution in the form of office space and the optimal use of resources.

- 33\% indicated that FWP would enable lecturers to focus on research, industry liaison and development of courseware.

- $20 \%$ reported their belief that FWP would have a positive impact on job satisfaction, motivation of employees and general morale.

- $15 \%$ indicated that performance appraisal would be objective as a result of assessment of performance based on outcomes.

The Australian and South African results show a similar pattern, with both countries indicating reduced absenteeism, greater loyalty and commitment and cost savings as potential benefits of flexibility. What was most evident from the Australian data was the use of FWP as a way of obtaining a competitive edge. The Australian data reported that FWP are used as a strategic tool to attract and keep productive employees (1999).

Potential disadvantages of FWP implementation as presented in Table 3 were identified as follows:

- $35 \%$ reported on the general lack of support systems, including resistance from management as well as administrative and technological support. The Australian data reported management commitment and an organisation with high level of technological infrastructure as critical success factors in the implementation of FWP.

- $31 \%$ indicated the unavailability of lecturers for students and general institutional activities as a disadvantage. This factor was supported by the Australian data, which indicated a general belief that FWP were incompatible with high quality customer service.

- $31 \%$ shared the perception that the system can be abused having a direct impact on productivity.

- $31 \%$ reported that FWP would negatively influence the coordination of work functions and, especially, functioning as a team.

- $20 \%$ responded that it would be difficult to control and supervise FWP.

- $16 \%$ reported that they believed FWP would have a negative impact on job security. In this regard $50 \%$ of Australian respondents believed that working on a flexible work arrangement would influence their promotional opportunities and thus hurt their career.

Table 2

FrequenCy DISTRIBUTION OF ADVANTAGES

\begin{tabular}{|c|c|c|c|c|c|c|c|c|c|c|c|c|}
\hline \multirow[t]{3}{*}{ Advantages: } & \multicolumn{12}{|c|}{ Number of responses by different stakeholders: } \\
\hline & \multicolumn{2}{|c|}{ Management } & \multicolumn{2}{|c|}{ Employees } & \multicolumn{2}{|c|}{ Union } & \multicolumn{2}{|c|}{ HR } & \multicolumn{2}{|c|}{ Students } & \multicolumn{2}{|c|}{ Total } \\
\hline & $\mathrm{f}$ & $\%$ & $\mathrm{f}$ & $\%$ & $\mathrm{f}$ & $\%$ & $\mathrm{f}$ & $\%$ & $\mathrm{f}$ & $\%$ & $\mathrm{f}$ & $\%$ \\
\hline Effective Time Utilisation. & 5 & $9 \%$ & 14 & $25 \%$ & & & 1 & $2 \%$ & 10 & $18 \%$ & 30 & $55 \%$ \\
\hline Increase productivity. & 5 & $9 \%$ & 18 & $33 \%$ & & & 1 & $2 \%$ & 1 & $2 \%$ & 25 & $45 \%$ \\
\hline Balance work and family life. & 6 & $11 \%$ & 14 & $25 \%$ & 2 & $4 \%$ & & & 1 & $2 \%$ & 23 & $42 \%$ \\
\hline Cost savings. & 11 & $20 \%$ & 7 & $13 \%$ & 1 & $2 \%$ & 1 & $2 \%$ & & & 20 & $36 \%$ \\
\hline $\begin{array}{l}\text { Time for research, industry liaison } \\
\text { and development work. }\end{array}$ & 2 & $4 \%$ & 13 & $24 \%$ & & & 1 & $2 \%$ & 2 & $4 \%$ & 18 & $33 \%$ \\
\hline Increase job satisfaction. & 2 & $4 \%$ & 7 & $13 \%$ & 1 & $2 \%$ & 1 & $2 \%$ & & & 11 & $20 \%$ \\
\hline $\begin{array}{l}\text { Performance appraisals more } \\
\text { objective. }\end{array}$ & 3 & $5 \%$ & 4 & $7 \%$ & & & 1 & $2 \%$ & & & 8 & $15 \%$ \\
\hline
\end{tabular}


TABLE 3

FREQUENCY DISTRIBUTION OF DISADVANTAGES

\begin{tabular}{|c|c|c|c|c|c|c|c|c|c|c|c|c|}
\hline \multirow[t]{3}{*}{ Advantages: } & \multicolumn{12}{|c|}{ Number of responses by different stakeholders: } \\
\hline & \multicolumn{2}{|c|}{ Management } & \multicolumn{2}{|c|}{ Employees } & \multicolumn{2}{|c|}{ Union } & \multicolumn{2}{|c|}{ HR } & \multicolumn{2}{|c|}{ Students } & \multicolumn{2}{|c|}{ Total } \\
\hline & $\mathrm{f}$ & $\%$ & $\mathrm{f}$ & $\%$ & f & $\%$ & $\mathrm{f}$ & $\%$ & $\mathrm{f}$ & $\%$ & $\mathrm{f}$ & $\%$ \\
\hline $\begin{array}{l}\text { Lack of support (management, } \\
\text { technological \& admin.) }\end{array}$ & 1 & $2 \%$ & 17 & $31 \%$ & & & & & 1 & $2 \%$ & 19 & $35 \%$ \\
\hline Unavailability of academic staff. & 3 & $5 \%$ & 8 & $15 \%$ & 1 & $2 \%$ & & & 5 & $9 \%$ & 17 & $31 \%$ \\
\hline $\begin{array}{l}\text { Take advantage of FWP } \\
\text { (abuse system). }\end{array}$ & 3 & $5 \%$ & 11 & $20 \%$ & 1 & $2 \%$ & 1 & $2 \%$ & 1 & $2 \%$ & 17 & $31 \%$ \\
\hline $\begin{array}{l}\text { Lack of coordination in work } \\
\text { functions. }\end{array}$ & 3 & $5 \%$ & 12 & $22 \%$ & 2 & $4 \%$ & & & & & 17 & $31 \%$ \\
\hline Difficult to control. & 2 & $4 \%$ & 6 & $11 \%$ & 2 & $4 \%$ & 1 & $2 \%$ & & & 11 & $20 \%$ \\
\hline FWP threat to job security. & & & 2 & $4 \%$ & 6 & $11 \%$ & 1 & $2 \%$ & & & 9 & $16 \%$ \\
\hline Staff not ready. & 1 & $2 \%$ & 6 & $11 \%$ & & & 1 & $2 \%$ & & & 8 & $15 \%$ \\
\hline FWP not applicable to all. & 1 & $2 \%$ & 6 & $11 \%$ & & & & & & & 7 & $13 \%$ \\
\hline Lack of social contact. & 4 & $7 \%$ & 2 & $4 \%$ & & & & & & & 6 & $11 \%$ \\
\hline
\end{tabular}

- $15 \%$ believed that employees might not be ready or may not have the self-management skills to work on a flexible basis.

- $13 \%$ indicated that a disadvantage was the fact that FWP would not be applicable to every position and that certain criteria would exclude individuals working on a flexible arrangement. This response was not applicable to the Australian data because of the identification of different options of flexibility that would suit different operational requirements.

- $11 \%$ responded that FWP would isolate employees through a lack of social contact and peer support.

An analysis of the responses on the disadvantages of FWP in both Australia a South Africa reflects uncertainty among the respondents. Emphasis is placed on soft issues e.g. limited social contact, lack of job security and self-management skills to work on a flexible basis. These are the factors that should be included in training and skill development. Of importance is the emphasis the Australian study placed on the involvement of all stakeholders in developing solutions to identified disadvantages (1999).

Potential barriers with regard to the effective implementation as presented in Table 4 were identified as follows:

- $35 \%$ indicated that the greatest barrier was management resistance and lack of support as well as the need for management to adopt different management styles and attitudes. The Australian data reported variation in the level of senior management support for the implementation of FWP. It appears that a high percentage of senior management was unconvinced of the business benefit of implementing flexibility.

- $31 \%$ believed that there was a general lack of a work ethic supportive of FWP. In this regard reference was made to the lack of training and communication, as well as several misconceptions concerning the implementation of FWP. The Australian data referred to the readiness of the individual to participate in FWP. Specific reference was made to the need for high levels of trust.

- $29 \%$ reported that the current performance management system could be seen as a barrier, especially the lack of clear performance standards and workload distributions. There was a general perception that the current performance management system could be linked to an increase in disputes on performance appraisals. The Australian data showed a similar pattern, by identifying a proper performance management system as a pre-requisite for the successful implementation of FWP.

- $22 \%$ viewed the lack of access to technology and support from the Information Technology Department (IT) as an additional barrier. In this regard special reference was made to the use of facilities at home and the possible reimbursement for this.

- $22 \%$ believed that the different options of FWP would not be applicable to every employee. Several respondents mentioned the need for policies and guidelines to be developed in order to determine who would be eligible for the different options. The Australian data showed a similar pattern but identified that traditional management styles and the perception of the nature of work influenced the outcome. Many managers believed that a range of activities could be performed in the workplace on a fulltime basis only.

- $20 \%$ expressed a concern for the ability of employees working on a flexible arrangement to sustain effective client services, just as a substantial majority reported on this issue in the Australian study.

- $13 \%$ believed that an additional barrier would be the lack in uniformity of policies and guidelines amongst different departments.

Possible solutions to the identified barriers as presented in Table 5 were identified as follows:

- $31 \%$ expressed the need for the institution to develop clear performance standards for employees working on a flexible basis and to assess performance based on outcomes and results and not on the hours worked. Reference was also made to regular feedback sessions.

- $29 \%$ believed that a communication and training strategy would need to be developed to assist the relevant stakeholders to understand and implement FWP.

- $27 \%$ stressed the importance of implementing a pilot study to introduce new flexible work practices according to operational requirements, to review the process continually to identify implementation difficulties and to evaluate the impact of FWP. The perception on the use of pilot studies was supported by the Australian data.

- $18 \%$ identified the need to expose management to training on their changing role in managing people working on a flexible arrangements, as well as on their commitment to 
TABLE 4

FREQUENCY DISTRIBUTION OF POTENTIAL BARRIERS

\begin{tabular}{|c|c|c|c|c|c|c|c|c|c|c|c|c|}
\hline \multirow[t]{3}{*}{ Advantages: } & \multicolumn{12}{|c|}{ Number of responses by different stakeholders: } \\
\hline & \multicolumn{2}{|c|}{ Management } & \multicolumn{2}{|c|}{ Employees } & \multicolumn{2}{|c|}{ Union } & \multicolumn{2}{|c|}{ HR } & \multicolumn{2}{|c|}{ Students } & \multicolumn{2}{|c|}{ Total } \\
\hline & $\mathrm{f}$ & $\%$ & $\mathrm{f}$ & $\%$ & $\mathrm{f}$ & $\%$ & $\mathrm{f}$ & $\%$ & $\mathrm{f}$ & $\%$ & $\mathrm{f}$ & $\%$ \\
\hline $\begin{array}{l}\text { Management resistance/lack . } \\
\text { of support }\end{array}$ & 2 & $4 \%$ & 15 & $15 \%$ & & & 2 & $4 \%$ & & & 19 & $35 \%$ \\
\hline $\begin{array}{l}\text { Lack of work ethic supportive } \\
\text { of FWP. }\end{array}$ & 6 & $11 \%$ & 9 & $16 \%$ & 1 & $2 \%$ & 1 & $2 \%$ & & & 17 & $31 \%$ \\
\hline Performance management system. & 4 & $7 \%$ & 12 & $22 \%$ & & & & & & & 16 & $29 \%$ \\
\hline Access to technology \& IT support. & & & 12 & $22 \%$ & & & & & & & 12 & $22 \%$ \\
\hline $\begin{array}{l}\text { FWP not applicable to all } \\
\text { employees. }\end{array}$ & 2 & $4 \%$ & 9 & $16 \%$ & 1 & $2 \%$ & & & & & 12 & $22 \%$ \\
\hline Client services. & 3 & $5 \%$ & 5 & $9 \%$ & & & & & 3 & $5 \%$ & 11 & $20 \%$ \\
\hline No policies \& guidelines. & 2 & $4 \%$ & 5 & $9 \%$ & & & & & & & 7 & $13 \%$ \\
\hline
\end{tabular}

TABLE 5

FREQUENCY DISTRIBUTION OF POTENTIAL SOLUTIONS

\begin{tabular}{|c|c|c|c|c|c|c|c|c|c|c|c|c|}
\hline \multirow[t]{3}{*}{ Advantages: } & \multicolumn{12}{|c|}{ Number of responses by different stakeholders: } \\
\hline & \multicolumn{2}{|c|}{ Management } & \multicolumn{2}{|c|}{ Employees } & \multicolumn{2}{|c|}{ Union } & \multicolumn{2}{|c|}{ HR } & \multicolumn{2}{|c|}{ Students } & \multicolumn{2}{|c|}{ Total } \\
\hline & $\mathrm{f}$ & $\%$ & $\mathrm{f}$ & $\%$ & $\mathrm{f}$ & $\%$ & $\mathrm{f}$ & $\%$ & $\mathrm{f}$ & $\%$ & $\mathrm{f}$ & $\%$ \\
\hline $\begin{array}{l}\text { Clear performance management } \\
\text { system. }\end{array}$ & 1 & $2 \%$ & 15 & $27 \%$ & & & 1 & $2 \%$ & & & 17 & $31 \%$ \\
\hline $\begin{array}{l}\text { Communication and training } \\
\text { strategy. }\end{array}$ & 6 & $11 \%$ & 9 & $16 \%$ & & & 1 & $2 \%$ & & & 16 & $29 \%$ \\
\hline Pilot study. & 4 & $7 \%$ & 10 & $18 \%$ & 1 & $2 \%$ & & & & & 15 & $27 \%$ \\
\hline Expose management to training. & & & 10 & $18 \%$ & & & & & & & 10 & $18 \%$ \\
\hline Involve all stakeholders. & & & 7 & $13 \%$ & 2 & $4 \%$ & & & & & 9 & $16 \%$ \\
\hline Proper control mechanisms. & 1 & $2 \%$ & 6 & $11 \%$ & & & & & & & 7 & $13 \%$ \\
\hline Criteria to determine eligibility. & 1 & $2 \%$ & 5 & $9 \%$ & & & & & & & 6 & $11 \%$ \\
\hline
\end{tabular}

support FWP. Reference was also made to the assistance management would need to implement a performancemanagement system based on outcomes, and to set realistic work goals and workloads.

- $16 \%$ were of the opinion that FWP could not be successfully implemented if all stakeholders were not actively involved. In this regard, reference was made to the unions and customers.

- $13 \%$ indicated that proper control mechanisms would need to be in place for addressing cases where the arrangements were abused as well as for terminating them where applicable. In this regard reference was also made to the issue of control over confidentiality of material an individual is working on.

- $11 \%$ indicated that criteria would need to be developed to determine who would be eligible to work on a flexible arrangement.

The training of managers at the Attorney General's Department (1999) was considered an important first step in gaining acceptance of FWP. Results from the Australian study indicated that many managers had limited knowledge and experience of FWP and that a clear strategy was needed to implement FWP with the strategic business plan. A substantial majority in the Australian study indicated the need for conflict and dispute resolution procedures to terminate working on a flexible arrangement compared to only $13 \%$ in South Africa. This can possibly be attributed to the integration of FWP into the broader business plan as well as the involvement of unions. The Australian data indicated that unions were supportive of certain types of flexibility compared to clear resistance from unions in South Africa.

\section{DISCUSSION}

From the results of the survey it appears that the different stakeholders believe that there are a number of sound business reasons for implementing more flexible employment practices as reported in the potential advantages. FWP can be an effective means to enable employees to balance their work and other life commitments, and from an organisational perspective this can be a positive means of reducing absenteeism. Although the implementation of FWP has the potential to increase job satisfaction and morale, it may also have an impact on quality client services. In this survey there 
was no clear distinction between the disadvantages and the barriers. Most stakeholders perceived the disadvantages to be a barrier as well. The unions perceived FWP as a threat to job security and a unilateral way of management to change conditions of employment, whereas employees placed emphasis on the lack of clear performance standards regarding performance management and lack of management support. This survey thus confirms research conducted in Australia within the Attorney General's Department (1999), which indicated that clear leadership was a major driver of effective implementation of FWP.

From the results it appears that much of the initial implementation work will have to be devoted to communicating about and training in FWP and correcting misconceptions. Introducing one or several flexible work arrangements entails managing basic change, because it is likely to affect all aspects of an organisation's systems, policies and practices. The findings of this survey indicate that all stakeholders should be involved and that FWP should have total commitment from top management in order for it to be more than just a one-time arrangement. The findings further support the use of pilot studies to identify implementation problems, to make adjustments and to test the adjustments. Of specific importance was the emphasis placed on control mechanisms and the measurement of outcomes. This study indicates that the outcome is that what the employee is contracted to do, and within FWP emphasis must be placed on the following:

- the development of clear performance standards for the employee working on a flexible basis;

- the assessment of performance on the basis of outcomes/ results and productivity;

- the setting of realistic goals and workloads; and

- ensuring equity in the allocation of types of work and responsibilities.

Respondents further indicated that the following need to be included in a model of implementation:

- ensuring that all employees, including those working off-site, feel connected;

- maintaining accessibility (in order to counteract the perception that FWP would compromise quality client services);

- determining eligibility; and

- investigating the impact of present legislation (especially with regard to hours worked and safety regulations).

This study can be used as a point of departure for further research on the implementation of FWP. There are, however, certain limitations which must be kept in mind when interpreting the findings.

Firstly, given the sample size and the short time frame involved, the findings should be treated as descriptive rather than generally transferable.

Secondly, a general observation during the analysis of the data indicated that most students completed only the questions on advantages and disadvantages, and that there was a general misunderstanding with regard to the questions on possible barriers and solutions. This can possibly be attributed to the lack of knowledge on FWP that according to Welman and Kruger (1999) must be a pre-requisite for using certain terminology in question formulation. The accuracy of information obtained from students is, therefore, questionable because of the possible unfamiliarity of concepts.

Thirdly, the poor response rate from the unions and the Department of Human Resources can possibly be attributed to the time frame in which the survey was conducted. The organisation was involved in a declared dispute that resulted in industrial action. The results, however, indicated that all stakeholders needed to be motivated to meet the challenge of the new labour-market environment.

\section{CONCLUSION}

The Australian and South African findings strongly confirmed that the following variables are positively associated with the adoption of greater flexibility:

- top management commitment;

- organisations with a high level of technological infrastructure;

- employees supporting specific work values e.g. trustworthy employees; and

- proper performance-management systems.

The results further allow the identification of a set of humanresource-management practices that underwrite the adoption of different FWP arrangements and can be seen as guidelines for the effective implementation of FWP. In Australia the use of FWP is highly correlated with a strategic approach to management. Flexibility is, therefore, the result of a deliberate strategy by the Australian government and not just a reaction to socio-economical circumstances. The results of this study are supportive, therefore, of many of the international research findings that have emerged in the past years concerning the movement towards greater flexibility in the workplace.

\section{REFERENCES}

Appia-Mfodwo, A. (1998). Flexible Work Practices: A Qualitative study in three South African Provinces. Unpublished master's thesis, Graduate School of Business Management, University of Cape Town.

Atkinson, J. (1984). Manpower strategies for flexible organisations. Personnel Management, August, 28-31

Attorney General's Department. (1999). Advancing flexibility: A case study in implementing flexible work practices. NSW Government Publication: Sydney.

Axel, H. (1996). Redefining corporate sabbaticals for 1990's. Research Bulletin no. 1005. New York: Conference Board.

Becker, B.E. \& Huselid, M.A. (1998). High performance work systems and firm performance: A synthesis of research and managerial implications. Research in Personnel and Human Resource Management, (16), 53-101.

Blyton, P. (1991). Researching flexibility. The Work Flexibility Review, (2), 69-70.

Betcherman, G. (1997). Changing workplace strategies: Achieving better outcomes for enterprises, workers and society. OECD: Paris.

Gittleman, M., Horrigan, M. \& Joyce, M. (1998). Flexible workplace practices: Evidence from a nationally representative Survey. Industrial and Labour Relations Review, October, 99-115.

Horwitz, F.M., Cameron, A., Brosnan, P. \& Walsh, P. (2000). Flexible Work Practices: Perspectives from the Southern Hemisphere. South African Journal of Business Management, 31 (2), 76-84.

Horwitz, F.M. (2001). Flexible Work Practices in South Africa: economic, labour relations and regulatory considerations. Industrial Relations Journal, 26 (4), 257-266.

Ichniowski, C., Kochan, T.A., Levine, D., Olson, C. \& Strauss, G. (1996). What works at work: Overview and assessment. Industrial Relations, July, 299-333.

Johnson, M. (1997). Teleworking in brief. Butterworth Heinemann: Oxford

Kling, J. (1995). High performance work systems and firm performance. Monthly Labour Review, May, 29-36.

Levine, D.J. (1990). Reinventing the workplace: How business and employees can both win. Brookings Institution: Washington DC. 
Locke, R., Kochan, K. \& Piore, M. (1995). Employment relations in a changing world economy. MIT Press: Cambridge.

McLagan, P. \& Nel, C. (1995). The age of participation: New governance for the workplace and the world. Randburg: Knowledge Resources.

Odendaal, A. \& Roodt, G. (1998). Corporate culture and participation: Independent constructs? Journal of Industrial Psychology, 24 (3), 14-21.

Olmsted, B. \& Smith, S. (1997). Managing in a flexible workplace. Amacom:New York
Organisaion for Economic Co-operation and Development. (1999). Employment Outlook. OECD Press: Paris.

Robbins, S.P., Millett, B. \& Cacioppe, R. (1998). Organisational Behaviour: Leading and managing in Australia and New Zealand. Prentice Hall Australia: Sydney.

Skyrme, D.J. (1994). Flexible Working: Building a lean and responsive organisation. Long Range Planning, 27, 98-110.

Welman, J.C. \& Kruger, S.J. (1999). Research Methodology for the Business and Administrative Sciences. Oxford University Press: Southern Africa. 